УДК 930.1: 94(477)

\title{
ТВОРЕННЯ УВО В УКРАЇНСЬКИХ ДОСЛІДЖЕННЯХ: ІСТОРІОГРАФІЧНИЙ ОГЛЯД
}

\author{
Наталія НАДУРАК \\ Державний вищий навчальний заклад \\ "Прикарпатський національний університет імені Василя Стефаника", \\ Івано-Франківський коледж, \\ вул. Шевченка, 57, 76018, Івано-Франківськ, Україна \\ e-mail:nnadurak@ukr.net \\ DOI: 10.15330/gal.32.159-169 \\ ORCID: 0000-0002-5978-1900
}

\begin{abstract}
У статті аналізуються основні особливості та рівень дослідження украӥнською історіографією процесу творення Української військової організації, покликаної продовжувати збройну боротьбу за украйнську державність. Автор визначає найбільш складні, дискусійні та найменш дослідженні питання процесу формування УВО та ї̈ діяльності у 1920-1923 рр., робить висновок, щчо саме украӥнські зарубіжні дослідження стали базою всіх сучасних вітчизняних розробок иієї проблеми. 3 'ясовано, що сучасна вітчизняна історіографія здебільшого успадкувала від української зарубіжної тенденції до спрощеного викладу історії УВО. Автор доходить висновку, що вже від початку 2000-х років в Украӥні з'явилася низка досліджень, у яких розглянуто актуальні та малодосліджені питання часу та місия виникнення УВО, ролі $Є$. Коновальця у процесі формування організаиії, однак висновки авторів досить часто $\epsilon$ дискусійними, отож, иі питання потребують подальшого більш детального дослідження.

Ключові слова: украӥнська зарубіжна історіографія, радянська історіографія, сучасна украйнська історіографія, Украӥнська військова організачія, украӥнський наџіоналістичний рух, Організація украӥнських націоналістів, Свген Коновалецьь.
\end{abstract}

Зважаючи на зростаюче зацікавлення сучасного суспільства та наукового світу до проблем історії українського визвольного руху 20-30-х рр. XX ст., набуває актуальності питання дослідження процесу формування українського націоналістичного руху й творення Української військової організації (УВО). Однак, великий інтерес до історії українського націоналістичного руху та поява вже від початку 90-х рр. ХХ ст. численних сучасних досліджень з теми, не стали запорукою об'єктивного та всебічного висвітлення проблеми, а навпаки сприяли появі численних видань ненаукового характеру, яким притаманні емоційність, упередженість, гіперболізація та суб'єктивність оцінок, котрі беруть свій початок з української зарубіжної та радянської історіографій. Узагальнений аналіз праць дослідників, що висвітлювали питання діяльності українського націоналістичного руху, здійснили відомі українські науковці Я. Примаченко, В. Футала, Д. Вєдєнєєв, Г. Биструхін ${ }^{1} .3$ характеристикою особливостей та цінності праць з історії УВО, зокрема, питання ії виникнення, у своїх розвідках виступили дослідники О. Дарованець, Б. Галайко, Н. Надурак².

\footnotetext{
${ }^{1}$ Примаченко Я. Л. Північноамериканська історіографія діяльності ОУН і УПА. Київ : Ін-т історії України НАН України, 2010. 182 с. ; Футала В. Історія вивчення суспільно-політичного життя українців у міжвоєнній Польщі (1921-1939). Дрогобич : Коло, 2010. 456 с. ; Ведєнєєв Д. В., Биструхін Г. С. Меч і тризуб. Розвідка і контррозвідка руху українських націоналістів та УПА. 1920-1945. Київ : Генеза, 2006. C. 22-94.

${ }^{2}$ Дарованець О. Організаційні початки УВО та формування ії структури (1920-1922). Украӥнський визвольний рух. Львів : Інститут українознавства ім. І. Крип'якевича НАН України, Центр досліджень визвольного руху, 2007. Збірник 11. С. 5-60 ; Галайко Б. До питання створення Української військової організації. Україна : культурна спадщина, національна свідомість, державність / НАН України, Інститут українознавства ім. І. Крип'якевича. Львів, 2009. Вип. 18 : Західноукраїнська народна республіка : до 90-річчя утворення. С. 389-395 ; Надурак Н. М. Український праворадикальний рух 1920-1941 рр.: історіографія : дис... канд. іст. наук : 07.00.06. Івано-Франківськ, 2013. 311 с.
} 


\section{0}

Проблема історії українського націоналістичного руху на сучасному етапі є однією 3 найбільш політизованих та обговорюваних у суспільстві й наукових колах. Потрібно пам’ятати, що український націоналізм мав історичне загальноєвропейське коріння, виник у наслідок поразки визвольних змагань українського народу 1917-1921 рр., як намагання в іншій підпільній військово-революційній діяльності продовжити боротьбу з окупантом й підготувати грунт для відкритого всенародного повстання. Саме в складних умовах європейської історії 20-30-х рр. $\mathrm{XX}$ ст., особливо популярними ставали праворадикальні рухи, що обстоювали необхідність здійснення докорінних суспільних та політичних змін рішучими, кардинальними методами дій, відкидали ліберально-демократичний стиль керівництва державою, пропагували ідею "природної спільноти" як виразу єдності держави та суспільства, якій мають бути підпорядковані індивідуальні та групові інтереси, а також сповідували етноцентризм та націоналізм. Однак, потрібно пам'ятати, відмінність українського націоналізму полягає у тому, що він був визвольним рухом бездержавної нації.

На сьогодні видано сотні досліджень присвячених історії українського націоналістичного руху, в яких автори висвітлили передумови, причини й процес його становлення у 20-х рр. ХХ ст. У рамках цих досліджень, увага істориків також була прикута до УВО, яка стала першоосновою руху і своєю діяльністю сформувала основні цілі та форми боротьби, які реалізовувала в подальшому Організація українських націоналістів $(\mathrm{O} У \mathrm{H})$. У зв'язку з цим, постає потреба в історіографічному аналізі рівня вивчення проблеми в працях українських дослідників, а також у визначенні найбільш складних та дискусійних питань процесу творення УВО, що $є$ метою даного дослідження. Історіографічне осмислення стану вивчення проблеми, дозволить продовжити іï грунтовне та якісне дослідження, а також стимулюватиме пошук конструктивних підходів у вирішенні питань, що вимагають залучення нових джерел і здійснення аналітичних узагальнень.

Стосовно досліджуваної проблеми, зазвичай виділяють три історіографічні школи: радянську, українську зарубіжну та сучасну. Характерною особливістю радянської історіографії була іiї спрямованість проти будь-яких проявів визвольного руху в Україні, який розглядався крізь призму антирадянської діяльності. Будучи продуктом комуністичної ідеологічно-політичної системи, праці радянських істориків 40-50-х рp. ХX ст. 3 історії українського націоналістичного руху були досить шаблонними, з популістсько-ідеологічним наповненням, у них були присутні невиправдані фактологічні помилки й інтерпретації. У світлі окремих фактів, вирваних з контексту подій, УВО показана “посібником польського та німецького режимів". Деякі автори намагалися виявити нібито керівну роль німецької влади у створенні УВО. Як рік заснування УВО часто вказувався 1921 р., основними завданнями - служба "німецькому імперіалізмові і польсько-шляхетському урядові” та провокування масових арештів комуністів, допомога польським властям у погромі їх революційних організацій. Фактичним керівником УВО радянські автори часто називали Р. Ярого ${ }^{3}$. Дуже коротко, з перекрученнями та фактологічними помилками висвітлили питання створення УВО С. Даниленко, В. Добрецова, Ю. Римаренко, В. Руднєв, В. Чередниченко й інші ${ }^{4}$. Лише в 90-х рр. ХХ ст., після розпаду Союзу Радянських Соціалістичних Республік (СРСР) і проголошення незалежності України, дослідники отримали доступ до спецфондів вітчизняних архівів і можливість об'єктивно розробляти проблеми національно-визвольного руху.

\footnotetext{
${ }^{3}$ Кожне слово, кожен крок їх - зрада / редкол.: П. Д. Сардачук та ін. Ужгород : Карпати, 1979. С. 38.

${ }^{4}$ Даниленко С. Т. Дорогою ганьби і зради. 2-е вид. Київ : Наукова думка, 1972. 339 с. ; Добрецова В. В. Націоналізм і релігія на службі антикомунізму: Про контрреволюційну діяльність буржуазно-націоналістичних і клерикальних організацій на західноукраїнських землях у 20-30-х роках та боротьбу проти наших прогресивних сил. Львів : Вища школа, 1976. 204 с. ; Римаренко Ю. І. 3 ким і проти кого : документально-публіцистичні нариси й статті. Київ : Дніпро, 1983. 348 с. ; Руднєв В. В. Українські буржуазні націоналісти - агентура міжнародної реакції. Київ : Держполітвидав УРСР, 1955. 216 с. ; Чередниченко В. Анатомія зради. Український буржуазний націоналізм - знаряддя антирадянської політики імперіалізму. Київ : Вид-во політичної літератури України, 1978. 334 с. ; Чередниченко В. П. Націоналізм проти нації. Київ : Політвидав України, 1970. 190 с.
} 
Зрозуміло, що в той час, коли Україна була в складі СРСР, а в історичній науці панувала офіційна марксистсько-ленінська ідеологія, лише українські зарубіжні історики мали можливість вивчати історію УВО й продукувати наукові дослідження. Однак, оскільки першодослідниками проблеми часто були колишні учасники руху, важливо враховувати приналежність або прихильність автора до Організації українських націоналістів “мельниківців" (ОУНм) чи Організації українських націоналістів “бандерівців" (ОУНб), зважаючи на що можна виокремити "мельниківський” та "бандерівський” напрями історіографії. Вперше передумови, процес та обставини становлення УВО дослідив у своїй праці один із провідних ідеологів українського націоналізму В. Мартинець ${ }^{5}$. Автор досить жваво висвітлив передумови та обставини створення УВО у 1920 р., відзначивши, що вона проектувалась не як галицька, а всеукраїнська організація, зважаючи на що, у Києві восени 1920 р. було створено Центральний Революційний Комітет на чолі 3 I. Андрухом ${ }^{6}$. Дослідник намагався якомога точніше подати хронологію заснування УВО та дані про іiі безпосередніх творців ${ }^{7}$. Визначаючи цілі новоствореної УВО, В. Мартинець зауважив, що тактика й методи ії боротьби були "найбільш зближені до тактики й методів організації ірландських сінфайнерів".

Найгрунтовніше дослідження діяльності УВО репрезентують історики П. Мірчук, представник “бандерівської” та 3. Книш “мельниківськоі” течій руху. Проаналізувавши джерела, П. Мірчук назвав найімовірнішою датою заснування УВО липень 1920 р., а місцем - Прагу, відзначивши, що остаточне організаційне оформлення УВО на західноукраїнських землях проведено навесні 1921 р. ${ }^{8}$ П. Мірчук, описуючи творення і ріст організаційної мережі УВО, з'ясував iї командний склад. Основне ядро організації складали старшини та стрільці українських армій, а поповнювала ії ряди студентська, робітнича та селянська молодь. Однак, досить мало уваги автор приділив висвітленню причин й обставин постання УВО, побіжно зазначивши, що цю подію визначила потреба зберегти організовані форми боротьби, щоб мати можливість у відповідний момент відновити існування військової формації й щоб зберегти військові кадри для продовження визвольної боротьби. В іншій праці П. Мірчук намагався показати роль постаті Є. Коновальця, як визначного організатора, його внесок у створення УВО 9 . На думку історика, концепція створення УВО була сформульована в 1920 р. на засіданні Стрілецької Ради у Празі. Саме з метою продовження боротьби на українських землях в умовах довготривалого періоду ворожої окупації, Є. Коновальцем був запропонований проект створення окремої підпільної військової організації і збройного підпілля ${ }^{10}$. П. Мірчук дотримувався думки, що від початку створення, саме завдяки Є. Коновальцю, УВО стояла на позиціях українського націоналізму, однак, через його відхід від керма організації на деякий час (19231924 рр.), перетворилась на "організацію військово-бойового характеру без чітко визначеного ідеологічно-політичного обличчя”, і лише з його поверненням УВО зазнала ідейної реорганізації й розпочала активну співпрацю 3 українськими молодіжними націоналістичними організаціями.

У збірнику “Срібна Сурма: Спогади й матеріали до діяння УВО” подано важливу інформацію про організаційне оформлення та початок діяльності УВО, ії учасників та керівників, цілі та методи дій ${ }^{11}$. 3. Книш дійшов висновку про вирішальний вплив старшин Січових Стрільців і $Є$. Коновальця на формування в кінці липня - серпні 1920 р. УВО як нової організації, що

\footnotetext{
${ }^{5}$ Мартинець В. Українське підпілля: Від У.В.О. до О.У.Н. : спогади і матеріяли до передісторії та історії українського організованого націоналізму. Вінніпег, 1949. 428 с.

6 Ibid. C. 24-25.

${ }^{7}$ Ibid. C. 31-40.

${ }^{8}$ Мірчук П. Нарис історії Організації Українських Націоналістів : в 2 т. Мюнхен ; Лондон ; Нью-Йорк : Українське Вид-во, 1968. Т. 1 : 1920-1939. С. 15-16.

${ }^{9}$ Мірчук П. С. Коновалець. (У 20-річчя смерти). Торонто : Ліга визволення України, 1958. 108 с. 10 Ibid. C. 73.

${ }^{11}$ Срібна сурма : статті й матеріяли до діяння Української Військової Організації / зібрав, упорядкував і зредагував 3. Книш. Торонто : Срібна Сурма, [б. р.]. Зб. 2 : Початки УВО в Галичині. 167 с.
} 
прийшла на зміну ліквідованій в липні 1920 р. Стрілецькій Раді ${ }^{12}$. Саме тому в кінці серпня 1920 р. два члени Стрілецької Ради у Львові Михайло Матчак і Ярослав Чиж організували перший командний осередок УВО, а вже 31 серпня у Празі на з'їзді було проголошено створення УВО й її Начальної Команди. О. Навроцький, що був членом першої Начальної Команди УВО, у своїй статті змалював не лише політичне становище на Західній Україні в момент постання УВО, а й роль Українського Горожанського Комітету (голова Степан Федак) в ії створенні та визначенні подальших напрямків діяльності ${ }^{13}$. Свій погляд на питання створення УВО у статті розкрив Г. Васькович, який вважав, що рішення про створення УВО належало саме Стрілецькій Раді Січових Срільців, яка останній раз зібралась у липні 1920 p. ${ }^{14}$. Він був переконаний, що уряд ЗУНР не мав ніякого впливу на це рішення, оскільки на той час перебував у конфлікті 3 Стрілецькою Радою, а сама УВО ніколи не була підлеглою йому ${ }^{15}$. Стаття О. Бойківа присвячена $Є$. Коновальцю містить чимало важливої інформації про фінансове та збройне забезпечення УВО на момент створення, хоча подекуди автор навіть гіперболізує роль Є. Коновальця в національно-визвольному русі, наприклад, стверджуючи про пряму вказівку останнього щодо створення $\mathrm{УBO}^{16}$. І. Кедрин-Рудницький у своїй статті згадав, що був присутнім у Відні в 1920 р. при розмові між $Є$. Коновальцем та Я. Чижем про створення таємної революційно-підпільної організації ${ }^{17}$. С. Шевчук у спогадах згадує про три осередки військових, які дали початок УВО: перший центр виник у таборах інтернованих у Чехословаччині українців, другий - організував О. Навроцький у Львові зі старшин Української галицької армії (УГА) та Січових стрільців, третій осередок очолював Ю. Головінський (входили О. Сеник, І. Паславський, І. Ришавий, Ф. Яцура, Хархаліс, І. Грицак) ${ }^{18}$.

3 проголошенням незалежності України вітчизняні історики та суспільство по-новому відкрили для себе чимало проблем національної історії, розпочався новий етап дослідження українського націоналістичного руху, зокрема, діяльності УВО. Однією із особливостей новітнього історіографічного етапу дослідження проблеми $\epsilon$ введення в науковий обіг великої кількості нових архівних та історіографічних джерел, публікація великих серій збірників документів та матеріалів, мемуарних і монографічних праць про національно-визвольний рух 20-50-х pp. XX ст. 3 середини 90-х рp. XX ст. українська історіографія поступово звільняється від впливу праць українських зарубіжних авторів, з'являються перші наукові роботи комплексного характеру з грунтовним висвітленням проблеми. Саме до таких слід віднести серію монографій А. Кентія, праці О. Красівського, І. Васюти, для яких характерними є грунтовна джерельна основа, прагнення до об'єктивного й неупередженого дослідження різноманітних аспектів та етапів визвольної боротьби ${ }^{19}$.

\footnotetext{
${ }^{12}$ Книш 3. Підгрунтя УВО. Срібна сурма : статті й матеріяли до діяння Украӥнської Військової Організації. Торонто : Срібна Сурма, б. р. Зб. 2 : Початки УВО в Галичині / зібрав, упорядкував і зредагував 3. Книш. С. 9-24.

${ }^{13}$ Навроцький О. Початки УВО у Львові. Срібна сурма : статті й матеріяли до діяння Української Військової Організаиії / зібрав, упорядкував і зредагував 3. Книш. Торонто : Срібна Сурма, [б. р.]. Зб. 2 : Початки УВО в Галичині. С. 25-62.

${ }^{14}$ Васькович Г. Євген Коновалець і Євген Петрушевич в 1920-1921 роках. Євген Коновалець та його доба. Мюнхен : Видання фундації ім. Є. Коновальця, 1974. С. 303-315.

${ }^{15}$ Ibid. C. 314-315.

${ }^{16}$ Бойків О. Командир - Державний Муж - Творець організованого націоналізму. Організачія Українських Наиіоналістів 1929-1954 : збірка статей у 25-ліття ОУН. Париж : Видання Першої Української Друкарні у Франції, 1955. С. 49-68.

${ }^{17}$ Кедрин-Рудницький І. Видатна індивідуальність. Свген Коновалещь та його доба. Мюнхен, 1974. C. 341-356.

${ }^{18}$ Шевчук С. Пора сказати правду про наші визвольні змагання добитися волі для Галицької землі. 1918 1939. Торонто, $1965.280 \mathrm{c}$

19. Т. 1 : Від Української Військової Організації до Організації Українських Націоналістів. 1920-1942. 332 с. ; Кентій А. В. Українська військова організація (УВО) у 1920-1928 рр.: короткий нарис. Київ : Ін-т історії України НАНУ, 1998. 81 с. ; Красівський О. Східна Галичина і Польща в 1918-1923 рр.: Проблеми взаємин : монографія. Київ : Вид-во УАДУ, 1998. 304 с. ; Красівський О. Я. Галичина у першій чверті
} 
А. Кентій розглянув створення УВО в липні-серпні 1920 р. й відзначив, що вона започатковувалась як регіональне об'єднання, яке з часом мало поширити свою діяльність на всі українські землі. Він з'ясував, що назва “УВО” з'явилася після 1924 р., тобто після розколу Військової Організації, в результаті чого виникли УВО і у 1926 р. ЗУНРО ${ }^{20}$. До того ж він припустив, що в липні 1920 р. у Празі питання про створення Всеукраїнської військової організації через розбіжності у середовищі колишніх вояків українських армій не було остаточно вирішено. За цих обставин $Є$. Коновалець і його однодумці започаткували УВО як регіональне об'єднання, плануючи 3 часом поширити його впливи і діяльність на усі українські землі ${ }^{21}$. Щодо мети творення УВО, то А. Кентій відзначив, що спочатку вона створювалася щоб "зберегти військові кадри, щоб вести далі боротьбу проти обидвох окупантів”, однак зважаючи на те, що перспективи війни на теренах України найближчим часом виявились примарними, діяльність УВО набула головним чином диверсійно-підривного спрямування стосовно польського окупаційного режиму і перейшла на нелегальне становище ${ }^{22}$. Описавши становлення УВО, iii організаційну структуру, історик підкреслив велике значення керівництва в ній $Є$. Коновальця, адже завдяки його зусиллям УВО помітно активізувала український національно-визвольний рух, зробила його більш динамічним і радикальним ${ }^{23}$. На думку А. Кентія, Є. Коновалець виявив себе гнучким політиком, здатним миттєво зреагувати на зміни в зовнішньополітичній $\mathrm{i}$ внутрішній обстановці в Україні, пристосувати до цього форми і методи роботи УВО.

У своїх дослідженнях О. Красівський розглянув дві теорії творення УВО: зверху, Стрілецькою Радою з Є. Коновальцем, та знизу, внаслідок об'єднання розрізнених військових організацій під керівництвом $Є$. Коновальця ${ }^{24}$. І. Васюта чітко визначив датою створення УВО 31 серпня 1920 р., коли у Празі відбувся з'їзд представників українських військових організацій за кордоном, де було обрано Центральний провід УВО, який очолив $Є$. Коновалець ${ }^{25}$.

На основі невідомих й маловідомих архівних джерел О. Кучерук у своїй монографії висвітлив питання творення УВО ${ }^{26}$. Він подав дані, що навесні 1920 р. у Луцьких таборах формувалися основні засади і первісна структура майбутньої УВО, спочатку під неусталеною назвою, а вже нарада у липні 1920 р. у Празі ухвалила організувати на рідних землях особливу збройну силу ${ }^{27}$. На окремих конференціях вироблено відповідні вказівки, полковник $Є$. Коновалець виїхав до Відня де був тодішній політичний осередок уряду ЗУНР, а інші старшини вернулися в рідні землі й одразу приступили у Львові, на підставі отриманих доручень, до створення військового осередку, що кермував би опірними збройними пунктами, які виникли в низці місцевостей на західноукраїнських землях. Історик зробив висновок, що справу створення УВО вирішено в Празі, а на ЗУЗ існували співзвучні елементи в стадії початкового формування й вони чекали тільки на керманича, а отже УВО задумувалася не як вузько галицька справа, а як загальноукраїнська і фактично прагнула перебрати на себе керівництво і організацію загальнонаціонального руху для боротьби за відновлення української державності. У липні 1920 р. у тій же Празі, за ініціативою групи старшин Січових Стрільців на чолі з Є. Коновальцем, відбувся з'їзд, на якому, визнано причиною “національної катастрофи” існування і дія трьох українських урядів (УНР, ЗУНР, УСРР), а отже військовики бачили себе окремою дієвою силою, січове керівництво зважуючи на обставини і розраховуючи на свої можливості роз-

XX ст. : Проблеми польсько-українських стосунків. Львів : Вид-во ЛФУАДУ, 2000. 416 с. ; Васюта I. К. Національно-визвольний рух у Західній Україні (1918-1939рр.). Украӥнський історичний журнал. 2001. № 6. С. 35-64 ; Васюта І. К. Політична історія Західної України (1918-1939). Львів : Каменяр, 2006. $335 \mathrm{c}$.

${ }^{20}$ Кентій А. Збройний чин українських націоналістів. 1920-1956 : історико-архівні нариси... С. 31.

${ }^{21}$ Кентій А. В. Українська військова організація (УВО) у 1920-1928 рр. : короткий нарис.....С. 16.

${ }^{22}$ Кентій А. Збройний чин українських націоналістів. 1920-1956 : історико-архівні нариси.... С. 35.

${ }^{23}$ Ibid. C. 41.

${ }^{24}$ Красівський О. Східна Галичина і Польща в 1918-1923 рр... С. 191.

${ }^{25}$ Васюта I. К. Національно-визвольний рух у Західній Україні (1918-1939рр.)... С. 37.

${ }^{26}$ Кучерук О. Рико Ярий - загадка ОУН. Львів : Піраміда, 2005. 212 с.

${ }^{27}$ Ibid. C. $34-35$. 
глядало власну структуру як реальний чинник у боротьбі за відновлення української державності ${ }^{28}$.

М. Ковальчук у своїх дослідженнях, розглянувши військово-політичну діяльність С. Коновальця й спираючись на маловідомі архівні документи, спогади сучасників, реконструював обставини зародження УВО у 1920-1921 pp. ${ }^{29}$ Історик вважає, що восени 1920 р. організація Січових стрільців фактично розпалася, а більша частина іi членів (Я. Чиж, М. Матчак, В. Кучабський, Г. Гладкий, а згодом Р. Дашкевич, І. Чмола та ін.) виїхала до Галичини, де протягом 1921 р. поступово закладали в середовищі ветеранів УГА організаційну сітку таємної військової організації, що повинна була розгорнути підпільну боротьбу проти польського режиму, при цьому львівський гурток Січових стрільців фактично діяв незалежно від Є. Коновальця й без його відома ${ }^{30}$. Також М. Ковальчук стверджує, що після проведення 1-3 липня 1921 р. у Львові українського студентського з'їзду, Є. Коновалець дійшов висновку, що центр політичної роботи потрібно перенести до Галичини і у липні 1921 р. переїхав до Львова, а наприкінці 1921 - на початку 1922 рр. місцеві Січові стрільці звернулись до нього з пропозицією очолити організацію ${ }^{31}$. Історик вважає, що саме протягом 1923-1924 pр. УВО остаточно перетворилася 3 осередку підготовки збройного повстання на революційно-терористичну групу $^{32}$.

Питання виникнення УВО висвітлив у своїх дослідженнях І. Гаврилів ${ }^{33}$, який вважає часом створення організації липень 1920 р. у Празі, стверджуючи, що основна маса українських воїнів була інтернована у таборах на території Чехословаччини, де українці отримали найбільше свобод і вже $з$ липня 1920 р. діяла військово-революційна організація "Воля", а 31 серпня у Празі відбувся з'їзд військовиків, в якому брали участь члени створених уже на еміграції організацій: “Воля”, "Молода Україна”, “Комітет української молоді” тощо ${ }^{34}$. Щодо оформлення УВО на західноукраїнських землях, то історик з'ясував, що в половині серпня 1920 р. до Львова прибули з Чехословаччини колишні інтерновані військовики (О. Навроцький, М. Матчак, Ю. Полянський, Я. Чиж, С. Кучабський, О. Кобєрський, Д. Паліїв, Б. Гнатевич, С. Федак та ін.), які створили Начальну команду і 2 вересня було видано наказ № 1, в якому в загальних рисах окреслено завдання військової організації як революційної, головною метою якої $\epsilon$ підготувати український народ i “викликати” загальнонародне повстання, яке силою зброї відновить Українську соборну національну державу ${ }^{35}$.

Важливим досягненням у дослідженні націоналістичного руху стало створення у 2002 p. у Львові “Центру досліджень визвольного руху" й видання серії збірників "Український визвольний рух”, де розкриваються різноманітні аспекти історії УВО ${ }^{36}$. У статті О. Дарованця досить грунтовно проаналізовано попередній науковий доробок з цього питання. Прообразом УВО історик назвав створену українськими старшинами у вересні 1918 р. у Львові нелегальну

\footnotetext{
${ }^{28}$ Кучерук О. Рико Ярий - загадка ОУН. Львів : Піраміда, 2005. С. 36.

${ }^{29}$ Ковальчук М. Біля витоків УВО: військово-політична діяльність Є. Коновальця у 1920-1921 рр. Украӥнський визвольний рух. Львів : Видавництво "Мс", 2006. 3б. 7. С. 5-78 ; Ковальчук М. До питання діяльності Є. Коновальця на чолі УВО та ОУН. Украӥнський визвольний рух. Львів : Інститут українознавства ім. І. Крип'якевича НАН України, Центр досліджень визвольного руху, 2010. Збірник 14. С. 5 32 ; Ковальчук М. На чолі Січових стрільців. Військово-політична діяльність Євгена Коновальця в $1917-$ 1921 рр. Київ : Українська видавнича спілка ім. Юрія Липи, 2010. 288 с.

${ }^{30}$ Ковальчук М. На чолі Січових стрільців... С. 186-187.

${ }^{31}$ Ковальчук М. Біля витоків УВО: військово-політична діяльність Є. Коновальця у 1920-1921 pр... С. 69.

${ }^{32}$ Ковальчук М. До питання діяльності Є. Коновальця на чолі УВО та ОУН С. 15.

${ }^{33}$ Гаврилів І. О. Західна Україна у 1921-1941 роках: нарис історії боротьби за державність : монографія. Львів : Видавництво Львівської політехніки, 2012. 472 с. ; Гаврилів І. О. УВО: підпільна армія в боротьбі за державність. Вісник Національного університету “Львівська політехніка". Львів : Видавництво Національного університету “Львівська політехніка”, 2006. № 572 : Держава та армія. С. 11-17.

${ }^{34}$ Гаврилів I. О. Західна Україна у 1921-1941 роках : нарис історії боротьби за державність... С. 93-94.

${ }^{35}$ Гаврилів І. О. УВО: підпільна армія в боротьбі за державність... С. 12.

${ }^{36}$ В'ятрович В. Центр досліджень визвольного руху: мета і завдання. Український визвольний рух. Львів, 2003. Збірник I. С. 5-9.
} 
Військову організацію. Щодо дати створення УВО, розглянувши численні джерела, автор підсумував, що найімовірніше, організаційні підвалини УВО (спочатку під назвами "Воля" та Військова організація) було закладено в другій половині 1920 р., а сам процес формування організаційної структури УВО фактично завершився до кінця 1921 p. $^{37}$. Відповідаючи на питання: хто виступив ініціатором створення УВО? - історик дійшов висновку, що каталізатором процесу творення УВО були Січові стрільці, колишні вояки КСС та УГА, причому перші виступили ініціаторами створення підпільної мережі і в Західній, і у Східній Україні, а другі стали кадровою основою організації в Галичині. Щодо ролі Є. Коновальця, то вказано, що він стояв безпосередньо біля ідеологічних та організаційних витоків УВО, завдяки цьому 1921 p. не виявилося серйозної альтернативи його кандидатурі на пост керівника УВО. Добре розглянуто в статті й організаційну структуру УВО, їі чисельність.

У статті Р. Забілого із залученням широкої джерельної бази розповідається про створення у грудні 1920 р. підпільної організації "Воля" - попередниці УВО на Долинщині (повітовий провідник В. Горбовий), яка стала досить потужною силою, здатною протистояти польському окупаційному режимові ${ }^{38}$. Історик вважає, що саме в Долині започатковано вид акцій, що їх невдовзі організація широко розгорнула в Західній Україні, - експропріаційні акти (“екси”), метою яких було здобуття коштів на бойову діяльність.

Про значення постаті Є. Коновальця у створенні УВО йдеться у статті В. В'ятровича, який зазначив, що поразка національно-визвольних змагань у 1921 р. для багатьох українських політиків стала шоком, який вони так і не зуміли подолати, перетворившись на еміграційних діячів, натомість для $Є$. Коновальця поразка навпаки стала поштовхом. Поява УВО, яка під гаслом “війна не закінчилась” продовжила боротьбу, засвідчила, що рух за незалежність вийшов на новий етап свого розвитку, подолав кризу поразки ${ }^{39}$. Історик подав дві існуючі версії заснування УВО. За однією з версій, пї початок закладено безпосередньо $Є$. Коновальцем на засіданні Стрілецької ради в Празі у липні 1920 р. За іншою - організація створена групою старшин Січових стрільців (сотники Ярослав Чиж, Василь Кучабський, Михайло Матчак) та Української галицької армії у Львові незабаром після відступу більшовиків. Точної дати створення організації назвати неможливо - вона губиться десь у бурхливих подіях 1920-1921 рр., підсумував В. В'ятрович. Він дійшов висновку, що в другій половині 1920 р. творяться підпільні групи, що згодом об'єдналися в єдину УВО. Ї̈і головною метою, як свідчить “Наказ № 1" 3 вересня того року (фактично перший документ, який засвідчує існування УВО), була боротьба проти польського панування в Галичині, тому й структура охоплювала саме цей терен, зазначив В. В'ятрович ${ }^{40}$.

Перебіг творення УВО розкрито у статті В. Манзуренка, який дослідив листи одного із засновників організації Ярослава Чижа ${ }^{41}$. Він припускає, що у Відні в 1920 р. українські військовики М. Матчак, В. Кучабський, Я. Чиж, А. Малецький і В. Целевич за погодженням 3 $€$. Коновальцем вирішили створити організацію, яка в краю набрала характеру підпільної УВО. Під кінець серпня 1920 р. у Львові два члени Стрілецької ради, сотник М. Матчак і сотник Я. Чиж, організовують перший командний осередок УВО. Пізніше тут було створено Начальну

\footnotetext{
37 Дарованець О. Організаційні початки УВО та формування іiі структури (1920-1922). Український визвольний рух. Львів : Інститут українознавства ім. І. Крип'якевича НАН України, Центр досліджень визвольного руху, 2007. Збірник 11. С. 5-60.

38 Забілий Р. Діяльність Української Військової Організації на Долинщині в 1920-1929 роках. Український визвольний рух. Львів : Інститут українознавства ім. І. Крип'якевича НАН України, Центр досліджень визвольного руху, 2008. Збірник 12. С. 5-22.

${ }^{39}$ В'ятрович В. Прецедент Коновальця. Украӥнський визвольний рух. Львів : Інститут українознавства ім. І. Крип’якевича НАН України, Центр досліджень визвольного руху, 2011. Збірник 16 : До 120-ліття з дня народження Свгена Коновальця. С. 15.

${ }^{40}$ В'ятрович В. Історія з грифом “секретно”: спочатку була УBO. URL: https://tsn.ua/analitika/istoriya-zgrifom-sekretno-spochatku-bula-uvo.html (дата звернення: 20.11.2018).

${ }_{41}$ Манзуренко В. Невідомі листи Євгена Коновальця в архіві Університету Міннесоти. Украйнський визвольний рух. Львів : Інститут українознавства ім. І. Крип'якевича НАН України, Центр досліджень визвольного руху, 2011. Збірник 16 : До 120-ліття з дня народження Євгена Коновальця. С. 36-40.
} 
колегію УВО, що складалася 3 чотирьох колишніх українських військовиків (М. Матчака, О. Навроцького, Ю. Полянського, Я. Чижа) та політичного діяча, судді В. Целевича. В. Манзуренко вказує, що на початку вересня 1920 р. Я. Чиж повідомив О. Навроцькому: “організаційна робота вже ведеться. Комендантом Української Військової Організації буде полк[овник] Євген Коновалець, він поки що в Відні, але старається якнайшвидше дістатися до Львова"42.

Б. Галайко у своїх статтях розглянув тогочасну ситуацію в Україні у 1919-1923 рр., щоб зрозуміти обставини виникнення УВО ${ }^{43}$. Він зазначив, що, на думку більшості дослідників, у липні 1920 р., коли Червона армія, завдавши кількох поразок польсько-українським військам, вела бойові дії проти поляків на теренах Східної Галичини та Західної Волині, у Празі відбулося засідання Стрілецької Ради, яке дало початок УВО, однак Б. Галайко піддав сумніву дане твердження через брак достовірних джерел ${ }^{44}$. Автор виділив дві версії заснування УВО. До одної зарахував тих дослідників, які стверджували, що рух опору виник спонтанно й було декілька організованих центрів боротьби, які без спротиву визнали примат одного центру, а до іншої, тих, які дотримувались думки, що УВО створили старшини Січових стрільців, а якщо й існували інші таємні організації, то вони були тимчасовими й не набули широкого впливу. Співставивши факти та свідчення, Б. Галайко підсумовує, що члени Стрілецької Ради, які прибули до Львова у 1920 р. (Я. Чиж, М. Матчак, В. Кучабський), зустріли вже достатньо добрий грунт у формі осередків самоорганізації колишніх військових-українців та таємних військових організацій, що лише починали зароджуватись (до прикладу осередок старшин УГА на чолі з Ю. Головінським, “Воля"), і власне саме вони, за допомоги активніших та впливовіших галичан (О. Навроцький, Д. Паліїв, В. Целевич, Ю. Полянський та ін.), зуміли сконсолідувати весь рух опору та об'єднати в одній структурі, що згодом стала відомою як УВО. Історик підкреслив, що УВО виникла в Галичині у 1920 р., як певний “новий” проект, який зумів об'єднати військових та цивільних різних політичних поглядів та переконань задля єдиної мети, а $€$. Коновалець у вдалий момент зрозумів перспективи формації нового зразка й, очоливши іiі, надав їй нового поштовху в роботі, прищепив соборницьку ідею, намагався розширити діяльність організації на територію усіх українських земель й таким чином продовжив боротьбу за здобуття української державності ${ }^{45}$. Б. Галайко, спираючись на дані польських органів безпеки, зазначив, що підпільна революційна українська організація остаточно сформувалася у кінці $1921 \mathrm{p}$.

Підсумовуючи, варто підкреслити, що внесок української зарубіжної історіографії у вивчення процесу творення УВО, попри сумнівний науковий рівень багатьох робіт, має неперехідне значення, оскільки саме вона окреслила головні напрями дослідження проблеми, стала базою всіх сучасних вітчизняних розробок даної теми. У той же час, у сучасній українській історіографії піднятої нами проблеми спостерігається позитивний процес активного критичного переосмислення концепцій діаспорних авторів.

Сучасна українська історіографія окресленої проблеми здебільшого, позитивно оцінює діяльність УВО в національно-визвольному русі українського народу, спрямовану на творення власної національної держави, а її виникнення вважає виявом загальноєвропейських тенденцій. Позитивом стало те, що сучасні дослідники проблеми намагаються базувати свої публікації на розлогому фактичному матеріалі, враховувати усю сукупність історичних обставин виникнення

\footnotetext{
42 Манзуренко В. Невідомі листи Свгена Коновальця в архіві Університету Міннесоти. Украйнський визвольний рух. Львів : Інститут українознавства ім. І. Крип’якевича НАН України, Центр досліджень визвольного руху, 2011. Збірник 16 : До 120-ліття з дня народження Свгена Коновальця. С. 38.

43 Галайко Б. До питання створення Української військової організації. Украӥна : культурна спадщина, національна свідомість, державність / НАН України, Інститут українознавства ім. І. Крип'якевича. Львів, 2009. Вип. 18 : Західноукраїнська народна республіка: до 90-річчя утворення. С. 389-395; Галайко Б. М. Військово-політичне становище на українських землях на початку 1920-х рр. та створення Української військової організації. Вісник Національного університету “Львівська політехніка”. Львів : Видавництво Національного університету “Львівська політехніка”, 2013. № 752 : Держава та армія. С. 129-136.

${ }^{44}$ Галайко Б. До питання створення Української військової організації... С. 390.

${ }^{45}$ Галайко Б. М. Військово-політичне становище на українських землях... С. 134.
} 
та діяльності українського націоналістичного руху. Нажаль сучасна вітчизняна історіографія цілком успадкувала від української зарубіжної тенденцію до спрощеного викладу історії УВО, лише в окремих розвідках є спроби з'ясувати хід подій, що започаткували творення УВО, виявити постаті засновників організації. У більшості зарубіжних діаспорних і сучасних вітчизняних праць початковий етап історії УВО детально не розглядається. Найчастіше автори цілковито зосереджують свою увагу на подіях другої половини $1920-\mathrm{x}$ рр., коли діяльність організації, очолюваної Є. Коновальцем, набула найбільшого розмаху. Проте вже від початку 2000-х рр. в Україні з'явилася низка досліджень, які містять важливу інформацію стосовно проблеми виникнення УВО. Вперше сучасними вітчизняними дослідниками розглянуто актуальні та малодосліджені питання часу та місця виникнення УВО, складу іiї справжніх засновників, ролі $€$. Коновальця у процесі формування організації, однак висновки авторів досить часто є відмінними та неоднозначними, отож, ці питання потребують подальшого більш детального дослідження на базі відповідних архівних фондів України та закордону. Нажаль історія УВО й досі залишається малодослідженою, неоднозначно трактованою, маловідомою для широкого загалу.

\title{
FORMATION OF UKRAINIAN MILITARY ORGANIZATION IN UKRAINIAN STUDIES: HISTORIOGRAPHICAL REVIEW
}

\author{
Natalia NADURAK \\ State Higher Educational Institution \\ "Vasyl Stefanyk Precarpathian National University", \\ Ivano-Frankivsk College, \\ Shevchenko St., 57, 76018, Ivano-Frankivsk, Ukraine, \\ e-mail:nnadurak@ukr.net
}

\section{Summary}

The article analyzes the main features and level of research in Ukrainian historiography of the process of creation of the Ukrainian Military Organization, intended to continue the armed struggle for Ukrainian statehood. At present, hundreds of studies devoted to the history of the Ukrainian nationalist movement have been published, in which authors highlighted the preconditions, causes and process of its formation in the 20's of the twentieth century. In these studies, the attention of historians was focused on the Ukrainian Military Organization, which became the basis of the Ukrainian nationalist movement. Its activity formed the main goals and forms of struggle that was further implemented by the Organization of Ukrainian Nationalists.

The author determines the most complicated, debatable and the least investigated issues of the process of formation of the Ukrainian Military Organization and its activity in 1920-23. She identifies three historiographical schools that studied this issue: Soviet, Ukrainian foreign and Ukrainian modern schools. It is emphasized that the characteristic feature of Soviet historiography was its orientation against any manifestations of the liberation movement in Ukraine, which was considered through the prism of anti-Soviet activity. The author concludes that Ukrainian foreign studies became the basis of all modern Ukrainian studies of this issue. First researchers of the problem often were former members of the nationalist movement. Therefore it is important to take into account their belonging to "melnykivtsy" or "banderivtsy", and distinguish between "melnykivsky" and "banderivsky" directions of Ukrainian foreign historiography.

It has been discovered that modern Ukrainian historiography inherited from the Ukrainian foreign historiography the tendency for a simplified representation of the history of the Ukrainian Military Organization. The author finds that one of the peculiarities of the latest stage of the study is the involvement of a large number of new archival and historiographical sources in the scientific circulation, the publication of large series of documents and materials, memoirs and monographs on the national liberation movement of the 20s and 50s of the twentieth century. Since the mid-1990s Ukrainian historiography is gradually released from the influence of works of Ukrainian foreign authors, and the first fundamental scientific works appeared.

The author concludes that since the beginning of the 2000's, a number of studies have been launched in Ukraine, in which actual and under-researched issues of the time and place of the emergence of the Ukrainian Military Organization and the role of Evhen Konovalets in the process of its formation were considered. However, the conclusions of the authors of such studies are often controversial, therefore, these issues need further detailed studies. 
It is concluded that modern Ukrainian historiography of this problem mostly evaluates positively the activity of the Ukrainian Military Organization in the national liberation movement of the Ukrainian people, aimed at the creation of its own national state, and its occurrence is considered as manifestation of panEuropean tendencies. The author emphasizes that modern researchers are trying to base their publications on a large factual material, they take into account the whole set of historical circumstances of the emergence and activity of the Ukrainian nationalist movement.

Keywords: The Green Holidays (Whitsunday), memorial events, solemn worship, memorable tables, national liberation fight, Galychina.

\section{REFERENCES}

Boikiv O. Komandyr - Derzhavnyi Muzh - Tvorets orhanizovanoho natsionalizmu. Orhanizatsiia Ukrainskykh Natsionalistiv 1929-1954 : zbirka statei u 25-littia OUN. Paryzh : Vydannia Pershoi Ukrainskoi Drukarni u Frantsii, 1955. S. 49-68. [in Ukrainian].

Cherednychenko V. Anatomiia zrady. Ukrainskyi burzhuaznyi natsionalizm - znariaddia antyradianskoi polityky imperializmu. Kyiv : Vyd-vo politychnoi literatury Ukrainy, 1978. 334 s. [in Ukrainian]. Ukrainian].

Cherednychenko V. P. Natsionalizm proty natsii. Kyiv : Politvydav Ukrainy, 1970. 190 s. [in

Danylenko S. T. Dorohoiu hanby i zrady. 2-e vyd. Kyiv : Naukova dumka, 1972. 339 s. [in Ukrainian].

Darovanets O. Orhanizatsiini pochatky UVO ta formuvannia yii struktury (1920-1922). Ukrainskyi vyzvolnyi rukh. Lviv : Instytut ukrainoznavstva im. I. Krypiakevycha NAN Ukrainy, Tsentr doslidzhen vyzvolnoho rukhu, 2007. Zbirnyk 11. S. 5-60. [in Ukrainian].

Dobretsova V. V. Natsionalizm i relihiia na sluzhbi antykomunizmu: pro kontrrevoliutsiinu diialnist burzhuazno-natsionalistychnykh i klerykalnykh orhanizatsii na zakhidnoukrainskykh zemliakh u 20-30-kh rokakh ta borotbu proty nashykh prohresyvnykh syl. Lviv : Vyshcha shkola, 1976. 204 s. [in Ukrainian].

Futala V. Istoriia vyvchennia suspilno-politychnoho zhyttia ukraintsiv u mizhvoiennii Polshchi (19211939). Drohobych : Kolo, 2010. 456 s. [in Ukrainian].

Halaiko B. Do pytannia stvorennia Ukrainskoi viiskovoi orhanizatsii. Ukraina: kulturna spadshchyna, natsionalna svidomist, derzhavnist / NAN Ukrainy, Instytut ukrainoznavstva im. I. Krypiakevycha. Lviv, 2009. Vyp. 18 : Zakhidnoukrainska narodna respublika: do 90-richchia utvorennia. S. 389-395. [in Ukrainian].

Halaiko B. M. Viiskovo-politychne stanovyshche na ukrainskykh zemliakh na pochatku 1920-kh rr. ta stvorennia Ukrainskoi viiskovoi orhanizatsii. Visnyk Natsionalnoho universytetu "Lvivska politekhnika". Lviv : Vydavnytstvo Natsionalnoho universytetu "Lvivska politekhnika”, 2013. № 752 : Derzhava ta armiia. S. 129136. [in Ukrainian].

Havryliv I. O. UVO: pidpilna armiia $\mathrm{v}$ borotbi za derzhavnist. Visnyk Natsionalnoho universytetu “Lvivska politekhnika”. Lviv : Vydavnytstvo Natsionalnoho universytetu “Lvivska politekhnika”, 2006. № 572 : Derzhava ta armiia. S. 11-17. [in Ukrainian].

Havryliv I. O. Zakhidna Ukraina u 1921-1941 rokakh: narys istorii borotby za derzhavnist: monohrafiia. Lviv : Vydavnytstvo Lvivskoi politekhniky, 2012. 472 s. [in Ukrainian].

Kedryn-Rudnytskyi I. Vydatna indyvidualnist. Yevhen Konovalets ta yoho doba. Miunkhen, 1974. S. 341-356. [in Ukrainian].

Kentii A. V. Ukrainska viiskova orhanizatsiia (UVO) u 1920-1928 pp. : korotkyi narys. Kyiv : In-t istorii Ukrainy NANU, 1998. $81 \mathrm{~s}$. [in Ukrainian].

Kentii A. Zbroinyi chyn ukrainskykh natsionalistiv. 1920-1956 : istoryko-arkhivni narysy. Kyiv, 2005. T. 1 : Vid Ukrainskoi Viiskovoi Orhanizatsii do Orhanizatsii Ukrainskykh Natsionalistiv. 1920-1942. 332 s. [in Ukrainian].

Knysh Z. Nachalna komanda UVO u Lvovi. Yevhen Konovalets ta yoho doba. Miunkhen : Vydannia fundatsii im. Ye. Konovaltsia, 1974. S. 288-297. [in Ukrainian].

Knysh Z. Pidgruntia UVO. Sribna surma: statti y materiialy do diiannia Ukrainskoi Viiskovoi Orhanizatsii. Toronto : Sribna Surma, [b. r.]. Zb. 2 : Pochatky UVO v Halychyni / zibrav, uporiadkuvav i zredahuvav Z. Knysh. S. 9-24. [in Ukrainian].

Kovalchuk M. Bilia vytokiv UVO: viiskovo-politychna diialnist Ye. Konovaltsia u 1920-1921 rr. Ukrainskyi vyzvolnyi rukh. Lviv : Vydavnytstvo "Ms", 2006. Zb. 7. S. 5-78. [in Ukrainian].

Kovalchuk M. Do pytannia diialnosti Ye. Konovaltsia na choli UVO ta OUN. Ukrainskyi vyzvolnyi rukh. Lviv : Instytut ukraino znavstva im. I. Krypiakevycha NAN Ukrainy, Tsentr doslidzhen vyzvolnoho rukhu, 2010. Zbirnyk 14. S. 5-32. [in Ukrainian].

Kovalchuk M. Na choli Sichovykh striltsiv. Viiskovo-politychna diialnist Yevhena Konovaltsia v $1917-$ 1921 rr. Kyiv : Ukrainska vydavnycha spilka im. Yuriia Lypy, 2010. 288 s. [in Ukrainian]. 
Kozhne slovo, kozhen krok yikh - zrada / redkol.: P. D. Sardachuk ta in. Uzhhorod : Karpaty, 1979.

112 s. [in Ukrainian].

Krasivskyi O. Skhidna Halychyna i Polshcha v 1918-1923 rr.: Problemy vzaiemyn : monohrafiia.

Kyiv : Vyd-vo UADU, 1998. 304 s. [in Ukrainian].

Krasivskyi O. Ya. Halychyna u pershii chverti XX st. : Problemy polsko-ukrainskykh stosunkiv. Lviv :

Vyd-vo LFUADU, 2000. 416 s. [in Ukrainian].

Kucheruk O. Ryko Yaryi - zahadka OUN. Lviv : Piramida, 2005. 212 s. [in Ukrainian].

Manzurenko V. Nevidomi lysty Yevhena Konovaltsia v arkhivi Universytetu Minnesoty. Ukrainskyi vyzvolnyi rukh. Lviv : Instytut ukrainoznavstva im. I. Krypiakevycha NAN Ukrainy, Tsentr doslidzhen vyzvolnoho rukhu, 2011. Zbirnyk 16 : Do 120-littia z dnia narodzhennia Yevhena Konovaltsia. S. 33-47. [in Ukrainian].

Martynets V. Ukrainske pidpillia: Vid U.V.O. do O.U.N. : spohady i materiialy do peredistorii ta istorii ukrainskoho orhanizovanoho natsionalizmu. Vinnipeh, 1949. 428 s. [in Ukrainian].

Mirchuk P. Narys istorii Orhanizatsii Ukrainskykh Natsionalistiv : v 2 t. Miunkhen ; London ; NiuYork : Ukrainske Vyd-vo, 1968. T. $1: 1920-1939.642$ s. [in Ukrainian].

Mirchuk P. Ye. Konovalets. (U 20-richchia smerty). Toronto : Liha vyzvolennia Ukrainy, 1958. 108 s. [in Ukrainian].

Nadurak N. M. Ukrainskyi pravoradykalnyi rukh 1920-1941 rr.: istoriohrafiia : dys kand. ist. nauk :

07.00.06. Ivano-Frankivsk, 2013. 311 s. [in Ukrainian].

Navrotskyi O. Pochatky UVO u Lvovi. Sribna surma: statti y materiialy do diiannia Ukrainskoi

Viiskovoi Orhanizatsii / zibrav, uporiadkuvav i zredahuvav Z. Knysh. Toronto : Sribna Surma, [b. r.]. Zb. 2 : Pochatky UVO v Halychyni. S. 25-62. [in Ukrainian].

Prymachenko Ya. L. Pivnichnoamerykanska istoriohrafiia diialnosti OUN i UPA. Kyiv : In-t istorii Ukrainy NAN Ukrainy, 2010. 182 s. [in Ukrainian].

Rudniev V. V. Ukrainski burzhuazni natsionalisty - ahentura mizhnarodnoi reaktsii. Kyiv : Derzhpolitvydav URSR, 1955. $216 \mathrm{~s}$. [in Ukrainian].

Rymarenko Yu. I. Z kym i proty koho: dokumentalno-publitsystychni narysy y statti. Kyiv : Dnipro, 1983. 348 s. [in Ukrainian].

Shevchuk S. Pora skazaty pravdu pro nashi vyzvolni zmahannia dobytysia voli dlia Halytskoi zemli.

1918-1939. Toronto, 1965. 280 s. [in Ukrainian].

Sribna surma: statti y materiialy do diiannia Ukrainskoi Viiskovoi Orhanizatsii / zibrav, uporiadkuvav i zredahuvav Z. Knysh. Toronto : Sribna Surma, [b. r.]. Zb. 2 : Pochatky UVO v Halychyni. 167 s. [in Ukrainian].

Vasiuta I. K. Natsionalno-vyzvolnyi rukh u Zakhidnii Ukraini (1918-1939 pp.). Ukrainskyi istorychnyi zhurnal. 2001. № 6. S. 35-64. [in Ukrainian].

Vasiuta I. K. Politychna istoriia Zakhidnoi Ukrainy (1918-1939). Lviv : Kameniar, 2006. 335 s. [in Ukrainian].

Vaskovych H. Yevhen Konovalets i Yevhen Petrushevych v 1920-1921 rokakh. Yevhen Konovalets ta yoho doba. Miunkhen : Vydannia fundatsii im. Ye. Konovaltsia, 1974. S. 303-315. [in Ukrainian].

Viatrovych V. Istoriia z hryfom "sekretno": spochatku bula UVO. URL: https://tsn.ua/analitika/istoriyaz-grifom-sekretno-spochatku-bula-uvo.html (data zvernennia: 20.11.2018).

Viatrovych V. Pretsedent Konovaltsia. Ukrainskyi vyzvolnyi rukh. Lviv : Instytut ukrainoznavstva im. I. Krypiakevycha NAN Ukrainy, Tsentr doslidzhen vyzvolnoho rukhu, 2011. Zbirnyk 16 : Do 120-littia z dnia narodzhennia Yevhena Konovaltsia. S. 14-16. [in Ukrainian].

Viatrovych V. Tsentr doslidzhen vyzvolnoho rukhu: meta i zavdannia. Ukrainskyi vyzvolnyi rukh. Lviv, 2003. Zbirnyk I. S. 5-9. [in Ukrainian].

Viedienieiev D. V., Bystrukhin H. S. Mech i tryzub. Rozvidka i kontrrozvidka rukhu ukrainskykh natsionalistiv ta UPA. 1920-1945. Kyiv : Heneza, 2006. S. 22-94. [in Ukrainian].

Zabilyi R. Diialnist Ukrainskoi Viiskovoi Orhanizatsii na Dolynshchyni v 1920-1929 rokakh. Ukrainskyi vyzvolnyi rukh. Lviv : Instytut ukrainoznavstva im. I. Krypiakevycha NAN Ukrainy, Tsentr doslidzhen vyzvolnoho rukhu, 2008. Zbirnyk 12. S. 5-22. [in Ukrainian]. 